\title{
A tribute to Antonín Vězda (1920-2008)
}

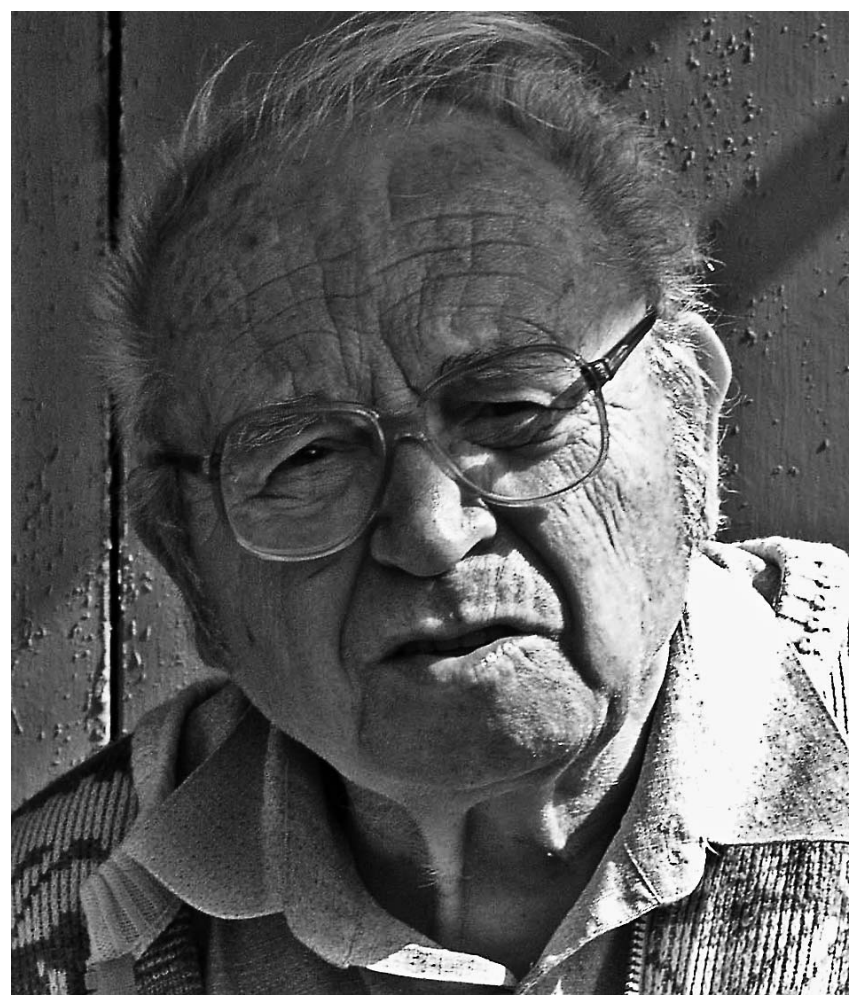

On 10 November 2008 lichenology lost one of its stars. Antonín ("Toni") Vězda - even his name comes close to the Czech word "hvězda" meaning "star" - was born on 25 November 1920 in Brno [Brünn], Czechoslovakia (now the Czech Republic), where he lived and studied. His address, "Tábor 28A" became known worldwide amongst lichenologists, most of whom he never met, as it appeared so often on correspondence and published papers; his apartment doubled as his office and herbarium. He was the first of the two sons of a printer who was interested in horticulture and mycology, perhaps one of the reasons for Vězda's interest in nature and cryptogams. After finishing his secondary school educa- tion, he was unable to continue his studies at a university due to World War II. However, he received two diplomas, in science and in forestry, and graduated at the Faculty of Sciences of the Masaryk (later J. E. Purkyně) University in 1947/1948 (cf. Šmarda \& Vězda 1948; Vězda 1950) and at the Faculty of Forestry of the Agricultural University in 1953. He then began teaching at the Agricultural University, but between 1958 and 1963 he had to make a living as a forest worker and technician. From 1963 onwards he was employed as a researcher by the Institute of Botany of the Czechoslovakian Academy of Sciences (later Academy of Sciences of the Czech Republic), Průhonice. Subsequently, he devoted himself entirely to the study of 
lichens and eventually defended his thesis for the Candidatus Scientiae degree (Vězda 1967). He was introduced to lichenology by J. Podpera, J. Nádvorník and Z. Černohorský (cf. Grummann 1974: 667). At first he dealt with local floristic, phytogeographical and ecological problems, but later his interest turned to lichen taxonomy, a life-long activity for which he became internationally renowned. His first interests were in the family Gyalectaceae s.lat. and the genera Bacidia and Micarea, the first species he described being Gyalecta cernohorskyi Vězda (Vězda 1958) and Gyalecta subscutellaris Vězda (Vězda 1960) [ $\equiv$ Gyalidea subscutellaris (Vězda) Vězda]; interestingly, the last species he described, Gyalecta canariensis v.d. Boom \& Vězda (van den Boom \& Vězda 2005) and Gyalideopsis pandani Vězda (Vězda 2007), belong to these groups.

Among foreign colleagues, the Swedish lichenologist A. H. Magnusson was particularly helpful in his earlier studies. With the compilation of the Lichenes Bohemoslovakiae Exsiccati (1957-1959), Vězda followed the traditions of J. Anders, K. Kavina, A. Hilitzer, V. Kut'ák, J. Nádvorník and J. Suza, whose specimens were well known to him, and within just two years he had edited and distributed 300 numbers in 10 fascicles; these increased his international contacts. With the subsequent Lichenes Selecti Exsiccati (1960-1991), which reached 2500 numbers, the highest output of any exsiccate ever published, he became famous among, and received praise from, colleagues and herbaria worldwide.

Since it was difficult to travel abroad from socialist countries at that time, Vězda travelled 'virtually' when he looked at the lichens from various parts of the world sent to him for study. However, he did travel locally and regionally at first, and based on the exsiccate schedae, it is possible to reconstruct his travel diary: the first specimen outside "Bohemoslovacia" was collected by him in Hungary (nr. 299. Physcia biziana (Mass.) Zahlbr. var. aipolioides Nádv.) in 1964 (Vězda 1964). In 1965 he visited France in the company of G. Clauzade and J. Lambinon, followed by trips to Yugoslavia (1966 - 1969), Austria (1967), Bulgaria (1967, 1968), Romania (1970), Sweden (1967) and Switzerland (1967). During this period he was also occupied with the preparation of the "Bestimmungsschlüssel Europäischer Flechten. Ergänzungsheft I-II" (Poelt \& Vězda 1977, 1981), having established contact with Josef Poelt, who wrote about their friendship in a paper shortly before his death (Poelt 1995). From the 1970s to the early 1990s, Vězda travelled to European countries whenever it was possible, most often to the Alps and the Mediterranean region with J. Poelt, H. Hertel, V. Wirth, P. L. Nimis, D. Puntillo and others.

Among the very first collectors who sent specimens to distribute in Lichenes Selecti Exsiccati were the Italians F. Cevasco and S. Barbaro (1960), the Hungarian Á. Boros (1961) and the American W. L. Culberson (1960). The final number of collectors of the 1979 taxa distributed grew to 308. The first exotic collections from J. Jeník (Ghana, 1966), S. Lisowski (Republic of Guinea, 1962), T. Pócs (Tanzania, 1969) and V. Samek (Cuba 1966, 1968) stimulated his interest in lichens of the tropics, resulting in his first papers on tropical foliicolous lichens (Vězda 1973, 1975). In a previous paper, he had already described Bacidia buxi from Buxus leaves (Vězda \& Vivant 1972), and had started to collect foliicolous lichens in the Caucasus (Colchis) in 1978 (cf. nr. 1569. Gyalidea phyllophila Vězda, in Vězda 1978). If any group could be considered Vězda's favourite, it was foliicolous lichens, and his floristic, taxonomic, and systematic studies added considerably to our knowledge of these fascinating organisms. Like most of his classic predecessors, Vězda obtained exotic collections to work upon from colleagues, but in his case, due to political restrictions, he was unable to travel to the tropics himself until the 1990s. He had already retired when he could finally visit such places as the Canary Islands (1993, 1994), Dominica (1996), New Zealand (1997), Malaysia (1997), and the Seychelles (2000), alone or with his Italian colleague $\mathrm{F}$. Ceni. He was overwhelmed when he was finally to see those 
lichens on which he had worked for decades in their natural environment. At this time, he started Lichenes Rariores Exsiccati (19922003), which eventually consisted of 500 numbers representing 468 taxa (supplied by 72 collectors) (see also Vězda 2004).

Although Vězda became internationally renowned for his work on exotic lichens, in all three of his exsiccates there were also many representative lichens from his native country collected by him and later by his younger colleagues (S. Bayerová, R. Dětinský, J. Horáková/J. Kocourková, J. Halda, E. Jelínková/E. Lisická, J. Liška, Z. Kyselová, Z. Palice, I. Pišút), showing that the lichens of his own locality remained just as important to him as those from any other part of the world. His Catalogue of Czech Lichens, long under preparation, was finally published in 1999 (Vězda \& Liška 1999). His very last publication (Vězda 2008) is a final treatment of his beloved Lichenes selecti exsiccati, an "Alphabetical index to all 2500 edited taxa of lichenized or lichenicolous fungi”.

According to Černohorský (1980), Vězda developed into a leading taxonomist of European standing and continued the line of excellent Czech and Slovak lichenologists, such as A. Hilitzer, J. Suza and M. Servít. The early history of lichenology was very much determined by Europe, and the 19th and early 20th century was the classic period for those defined as universal taxonomists, all having in common a broad knowledge of lichen taxonomy and disseminating their discoveries widely through prolific publications and the production of exsiccates, rather than teaching students, a tradition carried on by Vězda.

Vězda's output was prodigious: he published no fewer than 376 scientific papers between 1948 (Šmarda \& Vězda 1948) and 2008 (Vězda 2008), including 179 schedae and other compilations on his three exsciccata series, many of them containing descriptions of new taxa. He was the sole author of $70 \%$ of his papers; in $24 \%$ of the publications he had one co-author (mostly J. Poelt, W. Malcolm and K. Kalb) and in $6 \%$ of the papers there were three or more authors. His exsiccates are unequalled in terms of quan- tity and quality. He named 478 taxa, among them two families: Protothelenellaceae Vězda, H. Mayrhofer \& Poelt, Solorinellaceae Vězda $\&$ Poelt (with a further two families validated by other lichenologists: Thrombiaceae Poelt $\&$ Vězda ex J. C. David \& D. Hawksw., Vezdaeaceae Poelt \& Vězda ex J. C. David \& D. Hawksw.), 38 genera, and 399 species (and taxa of further taxonomic ranks: 4 sections, 4 series, 2 subspecies, 27 varieties and 2 forms), and he also proposed 282 new combinations (cf. Halda \& Vězda 2007; www. indexfungorum.org; whilst this number might not match those produced by Nylander or Müller Argoviensis, almost all of Vězda's taxa still exist (131 of his taxa have been recombined, 51 by Vězda), whereas many of the names ascribed by the 19th century lichenologists have been subsumed in synonymy.

In addition, there are his beautiful drawings (see e.g. the plates in Kalb \& Vězda 1988) which accompany almost all of his publications, an output of artwork only a few of his predecessors or colleagues could match. For his drawings he would first prepare sketches of sections of fruit-bodies or asexual reproductive organs (e.g. campylidia, asci, ascospores, hyphophores, diahyphae, conidia) and other important anatomical and morphological details on squared paper applied to a scale commensurate with that viewed under the microscope, without using any attached projection equipment. Afterwards he would redraw the sketches on white sheets and then arrange them into large plates, such as the one created for Macentina borhidii (Farkas \& Vězda 1987).

From his meticulous analysis of even the smallest morphological and anatomical details of the lichens he studied, Vězda also became deeply aware of phylogenetic relationships, although unlike his 19th and early 20 th century predecessors, he had the advantage of working in a period of great progress in lichen phylogeny and systematics, which facilitated his taxonomic studies. Vězda was also able to expand considerably our knowledge of lichens, one of the most striking examples being the appreciation of hyphophores, and the resurrection of the lichen family Gomphillaceae, which brought 
together such disparate taxa as Gomphillus and Aulaxina - whoever would have thought these genera to be closely related or even belonged to the same family, and in fact, few accepted his conclusions (Vězda \& Poelt 1987), but almost 20 years later, molecular studies proved him to be correct (Lücking et al. 2004). Besides the Gomphillaceae, Vězda also rearranged the foliicolous representatives of Zahlbruckner's collective family Lecideaceae and reintroduced the families Pilocarpaceae and Ectolechiaceae, the latter characterized by campylidia, another kind of unique conidiomata. Although campylidia are familiar to anyone looking at a tropical leaf surface, Vězda was the first to understand their true nature and systematic significance. He was not only one of the last universal taxonomists, and to many the most prominent one, he was also an outstanding example of one with a special gift of recognizing natural relationships through microscopy alone, without the need for DNA sequencing.

Vězda was an outstanding taxonomist, excellent collector and exceptional lichen specialist, as acknowledged by honorary memberships of the British Lichen Society, the Societa Lichenologica Italiana, the Czech Botanical Society, and the Czech Scientific Society for Mycology. He was also awarded the prestigious Acharius Medal of the International Association for Lichenology in 1992 and the Holuby Memorial Medal of the Slovak Botanical Society in 1995. A memorial volume of Scripta Lichenologica (Farkas et al. 1995) was dedicated to him on the occasion of his 75 th birthday. Taxa named after him include two genera, Vezdaea Tscherm.-Woess \& Poelt and Zevadia J. C. David \& D. Hawksw., and 25 species. His biographical and bibliographic details are summarized in a series of papers, the former, for example, in Grummann (1974), Černohorský (1980), Pišút (1990, 2001), Poelt (1993, 1995), Farkas et al. (1995), Wirth (1995, 2009) and Kocourková (2009) and the latter in Črnohorský (1980), Pišút (1990, 2001) and Krahulec \& Palice (2006). The taxa described by him are summarised in Halda \& Vězda (2007). The Herbarium Vězda (and also his remarkable collection of literature) is now deposited in the Institute of Botany of the Academy of Sciences of the Czech Republic, Průhonice and abbreviated as PRA-V.

Vězda was a sensitive and extremely modest person, definitely devoted to and respectful of science. There were, and still are, others like him, but his death probably marks the end of an era. With everyone now turning to molecular methods, we are losing good traditional taxonomists at an alarming speed, and there appears to be no new generation capable of filling the void he leaves.

Special thanks are due to Paul Kirk and Ken Hudson (CABI) for extracting data from www.indexfungorum. org database, and to Adam Flakus (Kraków), Zdenek Palice (Průhonice) and Josef Halda (Rychnov) who supplied literature sources. The first author is grateful to Tamás Pócs (Felsőtárkány) for putting her in contact with Vězda and to Gintaras Kantvilas (Hobart) for sharing important details about his contacts with Vězda. We are also most grateful to Jana Kocourková (Praha) for the photograph and to Mark Seaward for valuable comments on an earlier draft of this tribute.

\section{REFERENCES}

Černohorský, Z. (1980) RNDr. Ing. Antonín Vězda, CSc. -60 let. Preslia 52: 367-371.

Culberson, W. L., Egan, R. S. \& Esslinger, T. L. (2008) Recent literature on lichens. http://www.nhm.uio. no/botanisk/bot-mus/lav/sok_rll.htm] [Prepared for the web by E. Timdal; first posted 14.4.1997, latest update 2.3.2009.]

Farkas, E. E., Lücking, R. \& Wirth, V. (eds) (1995) Scripta Lichenologica - Lichenological Papers Dedicated to Antonín Vězda. Bibliotheca Lichenologica 58: $1-501$.

Farkas, E. \& Vězda, A. (1987) Macentina borhidii, eine neue foliicole Flechte aus Tansania. Acta Botanica Hungarica 33(3-4): 295-300.

Grummann, V. (1974) Biographisch-bibliographisches Handbuch der Lichenologie. Lehre: J. Cramer, Hildesheim: Verlag Dr. H. A. Gerstensberg.

Halda, J. P. \& Vězda, A. (2007) A list of new taxa of lichens and lichenicolous fungi published by Antonín Vězda 1958-2007 by himself or together with co-auctors [sic!]. Acta Musei Richnoviensis, sect. natur., 14: 69-92.

Kalb, K. \& Vězda, A. (1988) Neue oder bemerkenswerte Arten der Flechtenfamilie Gomphillaceae in der Neotropis. Bibliotheca Lichenologica 29: 1-80.

Kocourková, J. (2009) Antonín Vězda. 25 November 1920 - 10 November 2008. International Lichenological Newsletter 31(2): 28-29.

Krahulec, F. \& Palice, Z. (2006) Antonín Vězda - 85 years. International Lichenological Newsletter 38(2): 17-18. 
Lücking, R., Stuart, B. L. \& Lumbsch, H. T. (2004) Phylogenetic relationships of Gomphillaceae and Asterothyriaceae: evidence from a combined Bayesian analysis of nuclear and mitochondrial sequences. Mycologia 96: 283-294.

Pišút, I. (1990) RNDr. Ing. Antonín Vězda, CSc. - 70 rokov. Preslia 62: 376-377.

Pišút, I. (2001) RNDr. Ing. Antonín Vězda, CSc., octogenerian. Biologia (Bratislava) 56: 458-460.

Poelt, J. (1993) Presentations of the Acharius medals on 3 September 1992 in Båstad, Sweden: speeches. Antonín Vězda. International Lichenological Newsletter 26: 31-32.

Poelt, J. (1995) Antonín Vězda - der Mensch hinter dem Werk. Bibliotheca Lichenologica 58: 1-4.

Poelt, J. \& Vězda, A. (1977) Bestimmungsschlüssel europäischer Flechten. Ergänzungsheft I. Bibliotheca Lichenologica 9: 1-258.

Poelt, J. \& Vězda, A. (1981) Bestimmungsschlüssel europäischer Flechten. Ergänzungsheft II. Bibliotheca Lichenologica 16: 1-390.

Šmarda, J. \& Vězda, A. (1948) K poznání a ochraně krajinného rázu údolí západomoravských řek. 1 . Údolí Jihlavky u Templštýna. Ochrana Prirody (Naturae Tutela), Praha, 3: 101-104.

van den Boom, P. P. G. \& Vězda, A. (2005) Gyalecta canariensis sp. nov., a new lichen (Ascomycota) from La Palma (Canary Islands). Mycotaxon 92: 255-258.

Vězda, A. (1950) Vegetace na rokytenském slepenci v oblasti řeky Rokytné. Vlastivedny Věstnik Moravsky 5(2): 1-16

Vězda, A. (1958) Československé druhy rodu Gyalecta a Pachyphiale s kličem a přehledem evropských druhů. Sborník Vysoké Školy Zemědělské a Lesnické v Brně [Acta universitatis agriculturae et silviculturae, Brno]. Ser. C 1: 21-56.

Vězda, A. (1960) Flechten der tschechoslowakischen Karpaten III. Ergebnisse der lichenologischen Durchforschung im tschechoslowakischen Teile der Karpaten im Jahre 1958. Biologia (Bratislava) 15(3): 168-182.

Vězda, A. (1964) Lichenes Selecti Exsiccati, Editi ab Instituto Botanico Academiae Scientiarum Cechoslovacae, Prihonice prope Pragam. Fasc. XII. (No. 276-300), $6 \mathrm{pp}$.
Vězda, A. (1967) Taxonomická studie lichenizovaných hub čeledi Gyalectaceae sensu Zahlbruckner. I. Rody Gyalecta Ach., Gyalectina Vězda, Pachyphiale Lönnr. a Dimerella Trevis. Dissertation for the Candidatus Scientiae degree, University Karlovy Praha [Charles University Prague].

Vězda, A. (1973) Foliicole Flechten aus der Republik Guinea (W-Afrika). I. Casopis Slezskeho Muzea [Acta Musei Silesiae], Ser. A. (Opava) 22: 67-90.

Vězda, A. (1975) Foliicole Flechten aus Tanzania (Ost-Afrika). Folia Geobotanica et Phytotaxonomica (Praha) 10: 383-432.

Vězda, A. (1978) Lichenes Selecti Exsiccati Editi ab Instituto Botanico Academiae Scientiarum Cechoslovacae, Pruhonice prope Pragam. Fasc. LXIII (no. 15511575), $7 \mathrm{pp}$.

Vězda, A. (2004) Notes on the exsiccatum "Vězda: Lichenes rariores" with Index to fascicles 1-50 (Nos. 1-500). Czech Mycology 56(1-2): 151-162.

Vězda, A. (2007) Gyalideopsis pandani (lichenisierte Ascomycota, Gomphillaceae), eine neue Art aus Papua New Guinea. Bibliotheca Lichenologica 96: 305-309.

Vězda, A. (2008) Vězda: Lichenes selecti exsiccati (1960-1991) Alphabetical index to all 2500 edited taxa of lichenized or lichenicolous Fungi. Sauteria 15: 571-596.

Vězda, A. \& Vivant, J. (1972) Lichens épiphylles des Pyrénées-Atlantiques. Bulletin de la Société Botanique de France. 119: 253-258.

Vězda, A. \& Poelt, J. (1987) Flechtensystematische Studien XII. Die Familie Gomphillaceae und ihre Gliederung. Folia Geobotanica et Phytotaxonomica (Praha) 22: 179-198.

Vězda, A. \& Liška, J. (1999) Katalog lišejniků Ceské republiky. (A Catalogue of Lichens of the Czech Republic). Průhonice: Institute of Botany, Academy of Sciences of the Czech Republic.

Wirth, V. (1995) Begegnungen mit Antonín Vězda, mitgeteilt anlässlich seines 75 . Geburtstages. Aktuelle lichenologische Mitteilungen 11: 1-4.

Wirth, V. (2009) Antonín Vězda, der Lichenologe (1920-2008). Herzogia 22: 5-15.

Edit Farkas, Robert Lücking and Volkmar Wirth 